\title{
Determination of Physico-chemical Properties of Drinking Water in Merowe City, North Sudan
}

\author{
Mawia Hassan Elsaim ${ }^{1,2, ~ *, ~ S u m i a ~ A h m a d ~ N i m i r ~}{ }^{3}$, Muatz Salah ${ }^{4}$ \\ ${ }^{1}$ Department of Chemistry, Faculty of Science and Technology, University of Merowe, Merowe, Sudan \\ ${ }^{2}$ Department of Chemistry, College of Science, Beijing University of Chemical-Technology, Beijing, China \\ ${ }^{3}$ Department of Chemistry, Faculty of Education, University of Nile Village, Atbara, Sudan \\ ${ }^{4}$ Department of Chemistry, Faculty of Science, Sudan University of Technology, Khartoum, Sudan \\ Email address: \\ maelsaimhu7@gmail.com (M. H. Elsaim), maelsaimhu@yahoo.com (M. H. Elsaim) \\ ${ }^{*}$ Corresponding author
}

\section{To cite this article:}

Mawia Hassan Elsaim, Sumia Ahmad Nimir, Muatz Salah. Determination of Physico-chemical Properties of Drinking Water in Merowe City, North Sudan. World Journal of Applied Chemistry. Vol. 4, No. 4, 2019, pp. 52-58. doi: 10.11648/j.wjac.20190404.12

Received: August 27, 2019; Accepted: September 12, 2019; Published: October 12, 2019

\begin{abstract}
Water is one of the most important of all natural resources known on earth. It is important to all living organisms, most ecological systems, human health, food production and economic development. The safety of drinking water is important for the health. The safety of drinking water is affected by various contaminants, which included chemical and microbiological. Such contaminants cause serious health problems. The aim of this study was to determine the physico-chemical parameters quality of drinking water quality in Merowe city-north Sudan. The following water quality parameters were determined which were chosen as the major indicators namely PH, Total Dissolved Solid (TDS), Electrical conductivity (EC), Total hardness $(\mathrm{TH})$, calcium, sulphate, iron, nitrate, and nitrite. Our results show that the physical and chemical quality of the waters of Merowe city was high quality. All statistics was carrying out using SPSS version (16).
\end{abstract}

Keywords: Physico-chemical, TDS, Hardness, Conductivity, Turbidity, World Health Organization

\section{Introduction}

Water, the universal solvent as they call it, is absolutely essential for all forms of life but also for animal and vegetation, indeed it is part of life itself, since the protoplasm most living cells contains about 80 percent water and only substantial reduction in this amount occurs during the metabolism and growth of living cells [1]. The problem of supplying adequate of save water for distribution to the public doesn't end with the conservation of water works. The has been estimated that half of world's population has suffered from diseases caused by polluted water [2]. Water related diseases and illnesses are responsible for the loss of productivity and death of millions, perhaps even billion of people in the developing world. It has been reported that the death of the most of the children in Africa who die under the age of 5 is caused by integrate an safe water supplies [3]. The faceal oral disease includes the well-known water diseases that are often fatal, such as cholera and typhoid fever, but also the many common diarrhea disease. Diarrhea affects young children in developing countries contributing to malnutrition and death in fact, these diarrheal diseases are often responsible for more child mortality than any other cause of health [4]. Another important disease which make big problem is the goiter or thyroid glandwhich makes big problem to human health and this thought to be duet iodine deficiency. Monitoring the quality of water and applying corrective measures to polluted water before discharging in to the stream River and lakes act. Etc are some of very important controlling or mange going the water quality previous studies in Sudan have dealt only with certain aspect of water pollution problem. Contaminants are substances that are dissolved in water and make it unfit for use. Some contaminants can be easily identified only by assessing the taste, odorants turbidity of the water because pure water remains tasteless, colourless and odorless. However, most cannot be easily detected and require testing to reveal whether or not water is contaminated. Physico-chemical 
parameters of water are important to determine the quality of drinking water as according to WHO (1996) the physical parameters that are likely to give rise to complaint from consumers are colour, taste, odour and turbidity while low $\mathrm{pH}$ causes corrosion and high $\mathrm{pH}$ results in taste complaints. Recently in Merowe city drinking and general purpose water supplied by Nile, are very turbid therefore, it is expected to be contaminated with chemicals, just as well as microorganisms and accordingly it may cause health problem such as toxicity and some disease and disorders. Therefore, the present investigation was carried in an attempt to study the drinking water quality in Merowe city at different locations during twelve months with the objectives investigation the physical, and chemical, parameter of drinking water [5].

\section{Material and Methods}

This study was carried out in Merowe city, which is one of Merowe province localities northern state. Merowe city surround by Dongla locality north words, Abu Hamad province east words, Eldab locality in west words and desert to Khartoum in the south words. The study area is about $20 \mathrm{Km}^{2}$ and administratively is divided in to five units in addition to the water treatment unit, Eltamer, Elthora, Elsog, Eldoma, and Abu doom 250 water samples were collected from different sources in Merowe city (River Nile 10, Reservoir30, Flocculation tank 30, Sand Filter 30, Eltamer 30, Elsog 30, Elthora30, Eldoma30, Abu doom30).

Samples were collected in sterilised screw caped glass bottle. Insulated ice chest with ice packs was used from the collection of samples. The collected samples were labelled with date and code and kept at $4{ }^{\circ} \mathrm{C}$ until analyzed.

Immediately after sample collection, taste, $\mathrm{pH}$, conductivity and TDS were determined. The panel of 10 laboratory analysts and co-workers only for tested the tasteacceptable/not acceptable. The turbidity of water sample was directly determined by the portable turbidimeter (Jenway 6035) at room temperature, $\mathrm{pH}$ was carried out at room temperature by portable $\mathrm{pH}$ meter (Jenway 370) after calibrated with $\mathrm{pH} 7$ and 4 buffer. Conductivity and TDS were carried out at $25^{\circ} \mathrm{C}$ by conductivity meter (Jenway 470) after calibration with calibration solution (HI-031, Henna instrument Hungry). Calcium standard solution was prepared by dissolving 1.00gm $\mathrm{CaCO}_{3}$ (Scharlau Chemie, CA 0184) in $1 \mathrm{~L}$ volumetric flask. Add $200 \mathrm{ml}$ deionised water and add drop wise concentrated $\mathrm{HCl}$ until $\mathrm{CaCO}_{3}$ dissolved. Boil for few 5 minutes to expel the $\mathrm{CO}_{2}$. Cool and the make up the volume $1 \mathrm{~L}$. To prepare $0.01 \mathrm{M}$ EDTA solution $3.723 \mathrm{gm}$ $\mathrm{Na}_{2}$ EDTA. $\mathrm{H}_{2} \mathrm{O}$ (Scharlau Chemie, AC 0963) was weighed and dissolved in distilled water followed made up to $1 \mathrm{~L}$. To prepare indicator powder mixed $0.5 \mathrm{gm}$ of erichrome black $\mathrm{T}$ (Fluka, 45600) in 100gm of $\mathrm{NaCl}$ (Scharlau Chemie, SO 0227). Total hardness was determined by taking $10 \mathrm{ml}$ of water sample and dilute to approximately $50 \mathrm{ml}$ with deionised water. Add 1 to $2 \mathrm{ml}$ buffer solution ( $\mathrm{pH} 10$ ). Add 250mg Sodium Cyanide (Scharlau Chemie, SO 0190) and $200 \mathrm{mg}$ indicator powder, shake well. Titrate within 5 minutes with EDTA standard solution slowly with continuous stirring until reddish tinge disappeared [5].

\section{Results and Discussion}

The results of the present's study of water quality and assessment of parameters (physical and chemical) are present in table 1. The samples from all the areas were colorless and odorless. Temperature is one of the most important factors in the aquatic environment. It affects the physical and chemical properties of water and affects the aquatic vegetation; the temperature of all samples in range varies from $46^{\circ} \mathrm{C}$ to $47^{\circ} \mathrm{C}$.

Table 1. Physical properties of water samples from the area of the study and WHO.

\begin{tabular}{|c|c|c|c|c|c|c|}
\hline $\begin{array}{l}\text { Sample } \\
\text { Location }\end{array}$ & PH values & TurbidityNTU & $\begin{array}{l}\text { Electricalconductivity } \\
\text { (EC) }\end{array}$ & $\begin{array}{l}\text { Alkalinity as } \\
\mathrm{CaCO}_{3} \mathrm{mg} / \mathrm{l}\end{array}$ & $\begin{array}{l}\text { Total Hardness as } \\
87 \mathrm{CaCO}_{3} \mathrm{mg} / \mathrm{l} \\
\end{array}$ & $\begin{array}{l}\text { Total Dissolved } \\
\text { solids mg/l }\end{array}$ \\
\hline WHO & $6.50-8.50$ & 5 & 1600 & $500-1000$ & 500 & 1000 \\
\hline River & $9.01-8.02$ & $32.93-32.00$ & $300-208$ & $90-88$ & $95-90$ & 139.74-133.92 \\
\hline Reservoir & $8.3-7.21$ & $32.97-32.34$ & $310-239$ & $100-89$ & $109-101$ & $167.13-165.16$ \\
\hline Flocculation & $8.85-8.00$ & $27.92-22.13$ & $229-200$ & $97-76$ & $89.22-52.96$ & $135.22-122.16$ \\
\hline Filter tank & $8.01-7.72$ & $19.5-15.31$ & $225-180$ & $91-62$ & $75.74-69.9$ & 123.01-101.92 \\
\hline Eltamer & $8.00-7.58$ & $14.98-11.44$ & $197-163$ & $83-67$ & $72.33-69.33$ & $112.84-101.90$ \\
\hline Elsog & $7.95-7.39$ & $16.65-11.62$ & $181-162$ & $79-64$ & $72.36-69.94$ & $112.62-101.56$ \\
\hline Elthora & $7.92-7.32$ & $15.9-11.64$ & $178-163$ & $79-64$ & $72.39-69.97$ & $112.68-101.56$ \\
\hline Eldoma & 7.96-7.32 & $19.5-11.24$ & $194-138$ & $79-60$ & $72.37-69.94$ & $119.78-101.90$ \\
\hline Abu doom & $8.01-7.74$ & $18.92-13.74$ & $225-14$ & $89-62$ & $72.38-69.96$ & $123.01-103.71$ \\
\hline
\end{tabular}

\section{1. $\mathrm{PH}$}

From table 1, figure 1 the active hydrogen concentration $(\mathrm{pH})$ falls in the range 7.21 to 9.01 indicating that, all samples are slightly alkaline and the $\mathrm{pH}$ values obtained for each sample falls in the permissible range reported by SSMO causing no objectionable to the consumer. $\mathrm{pH}$ is one of the importance on determining the corrosively of water because generally the lower the $\mathrm{pH}$, thehigher the level of corrosion (WHO, 1996). Cautious attention to $\mathrm{pH}$ is necessary at all stages of water treatment before distribution to ensure satisfactory clarification and disinfection to minimise the corrosion of water. The $\mathrm{pH}$ values of water sample are between 7.21 to 9.01. All the results were below the permissible limit prescribed by WHO (1984) as $8.5 \mathrm{mg} / \mathrm{l}$. The highest $\mathrm{pH}$ was absorbed of sampling location river (9.01) 
while the lowest $\mathrm{pH}$ was detected at sampling location Reservoir (7.21) physico-chemical Studies river and net work water in and around Merowe city, north Sudan and observed the $\mathrm{pH}$ concentrations ranged from 7.21 to 9.01 . [6]

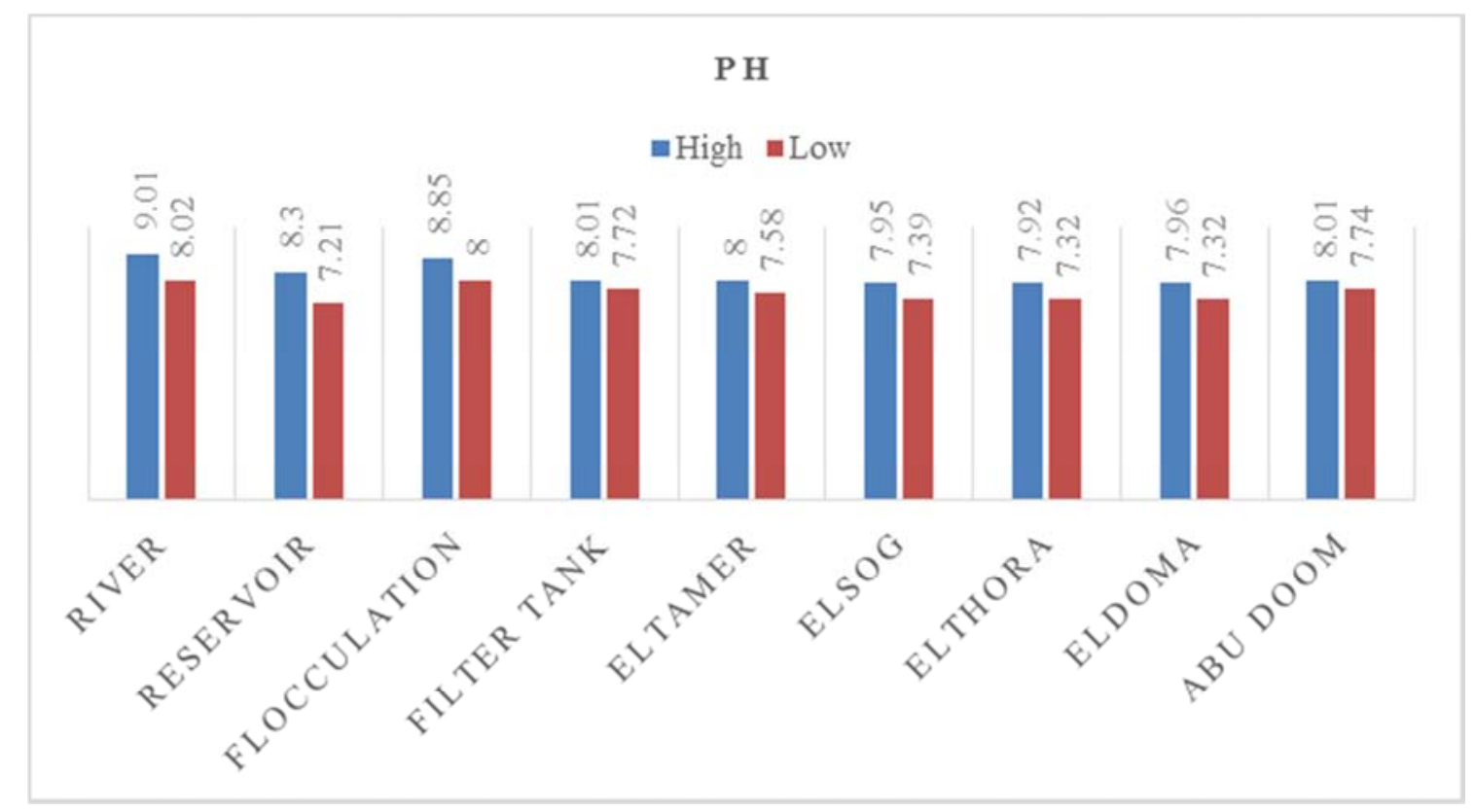

Figure 1. PH values level among various types of drinking water sources in Merowe city.

\subsection{Turbidity}

Turbidity makes water unfit for domestic purposes, food and beverage industries and many otherindustrial uses. $\mathrm{WHO}$, guidelines for turbidity are $<5 \mathrm{NTU}$. All natural waters are turbid but generally surface than ground water. From table 1, figure 2 turbidity values varied between 11.24 to 32.97 NTU for samples (Eldoma\& Reserviour) respectively and this indicating that turbidityhigh in all sample accept
(Reserviour) than the normal limit prescribed by WHO. Turbidity depends on a number of factors such as the size, shape, and refractive index of the clay, colloidal particles and the micro-organisms. The consumption of high turbid water would be a health risk due to microorganism as the probable part in it. Further turbidity can also protect the pathogens from the effects of disinfectants, facilitate their growth and increase the chlorine demand (WHO, 1996) [7].

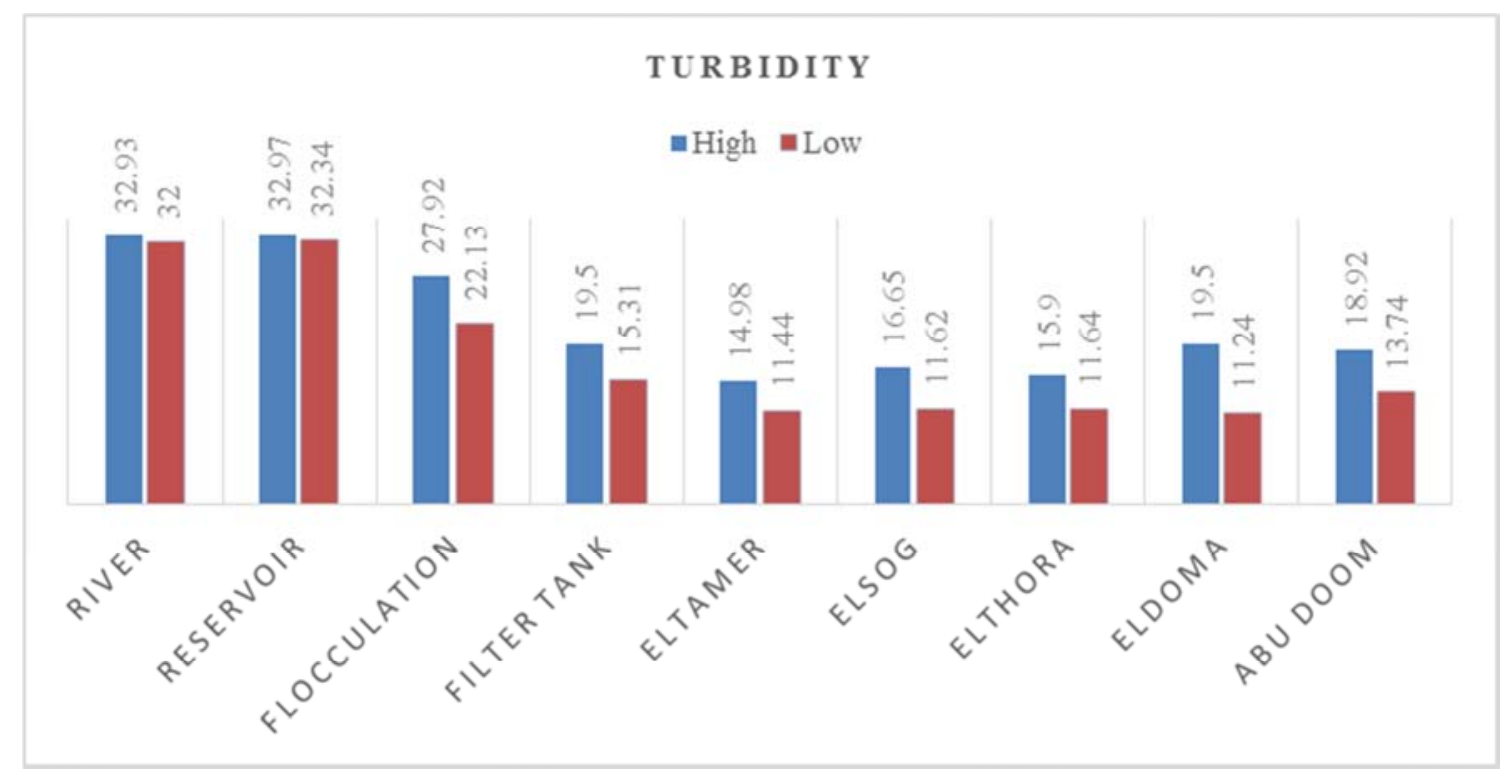

Figure 2. Turbidity values level among various types of drinking water sources in Merowe city.

\subsection{Electrical Conductivity (EC)}

Electrical conductivity is capacity of water to convey electric current. It indicates the amount oftotal dissolved salts. From table 1, figure 3 EC values were observed in the range of 14 to 310 . Electrical conductivity values obtained for each sample falls in the permissible range reported by SSMO and WHO causing no objection ble to the consumer. 


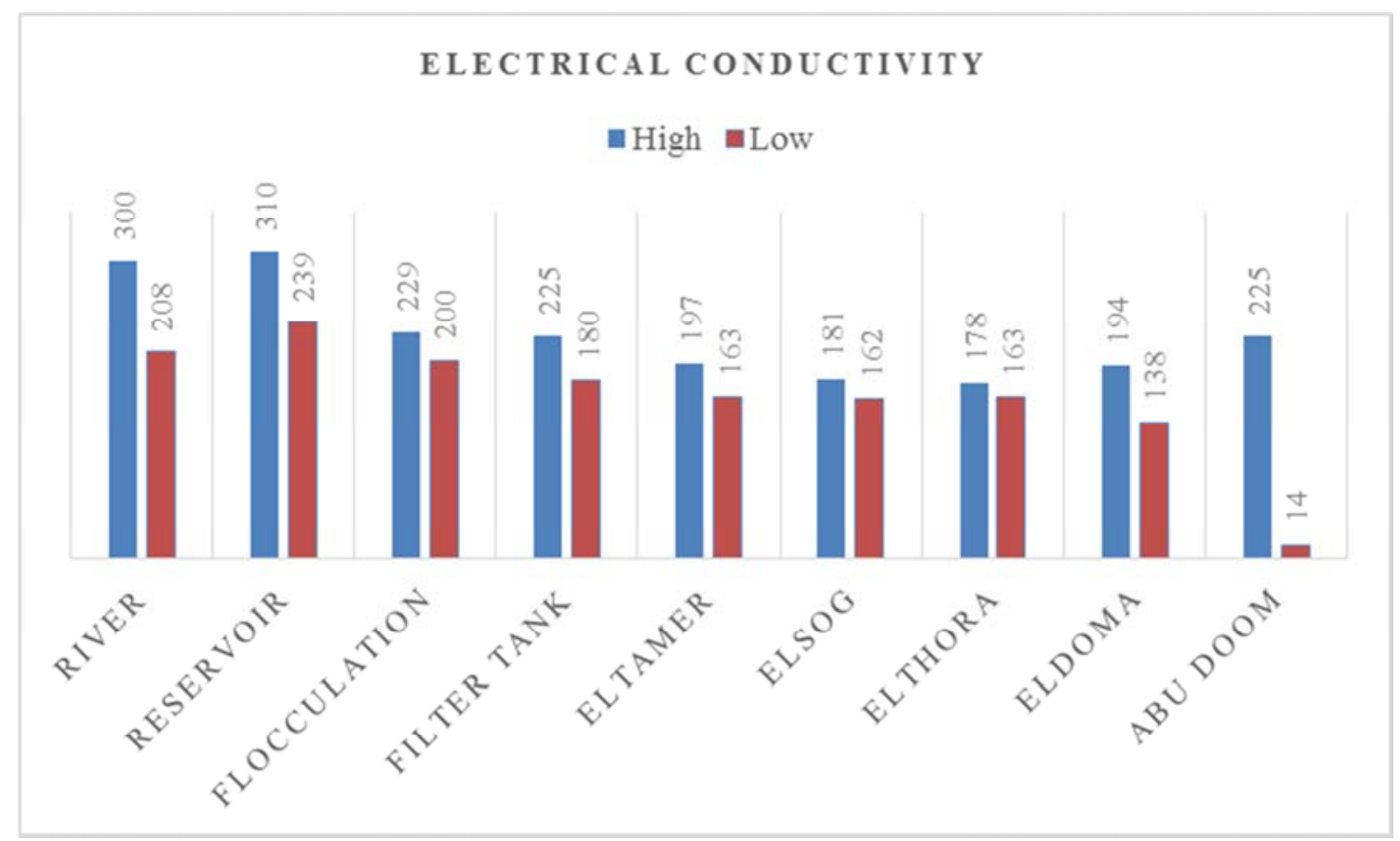

Figure 3. Electrical conductivity values level among various types of drinking water sources in Merowe city.

\subsection{Total Alkalinity}

From table 1, figure 4 the permissible value of alkalinity as recommended by WHO $500 \mathrm{mg} / \mathrm{L}$ as $\mathrm{CaCO}_{3}$. The amount of alkalinity concentration of the water sample collected in from the study area ranged from 60 to $100 \mathrm{mg} / \mathrm{L}$ was found within permissible range.

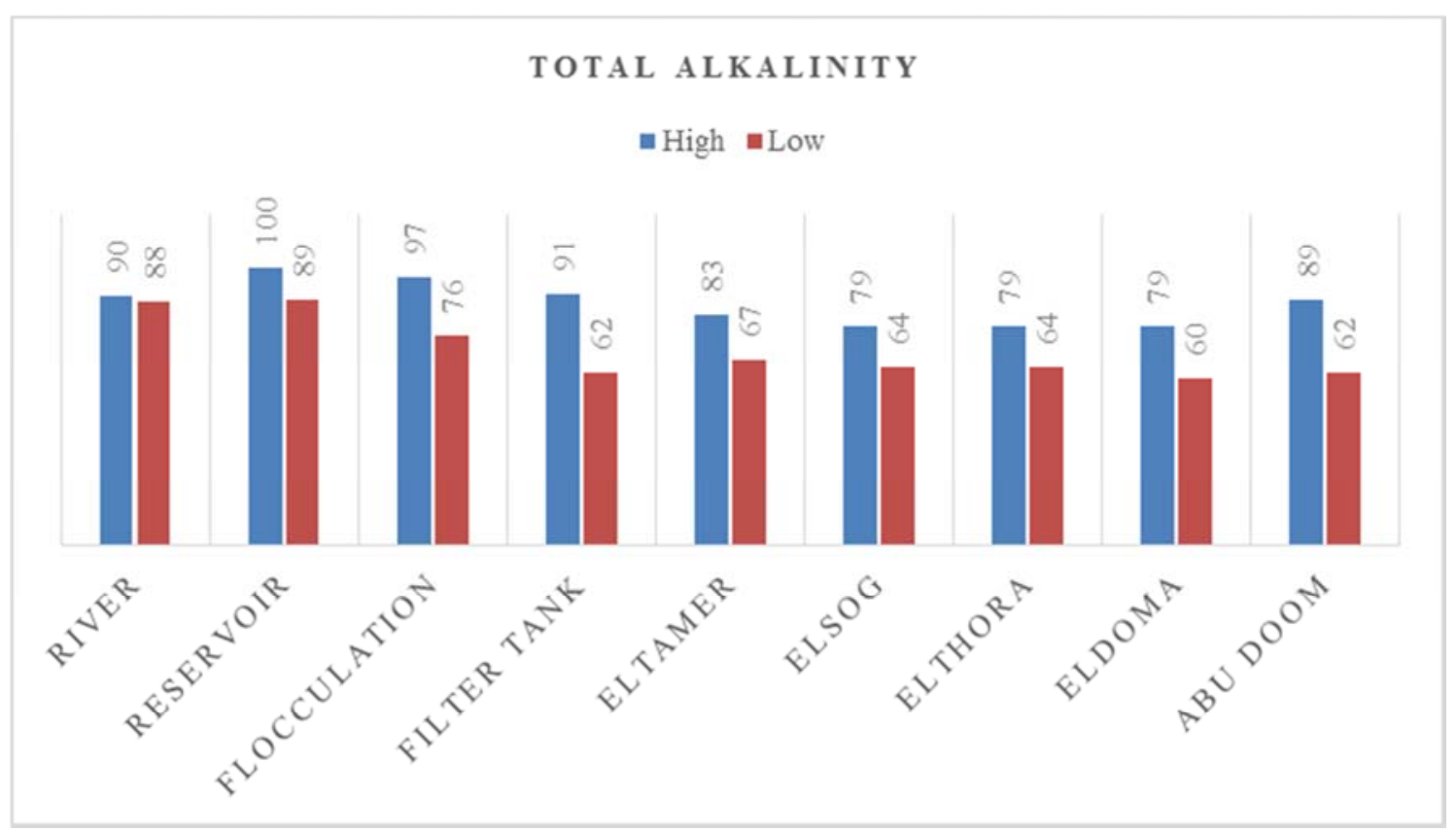

Figure 4. Total Alkalinity values level among various types of drinking water sources in Merowe city.

\subsection{Total Hardness (TH)}

Hardness in water is due to the natural accumulation of salts from contact with soil andgeological formations or it may enter from direct pollution by industrial effluents. Hardness ofwater mainly depends upon the amount of calcium or magnesium salts or both. Fromtable 1, Figure 4 total hardness valuesof water samples varied between 52.96 to 109 , indicating that these values within permissible range [8]. 


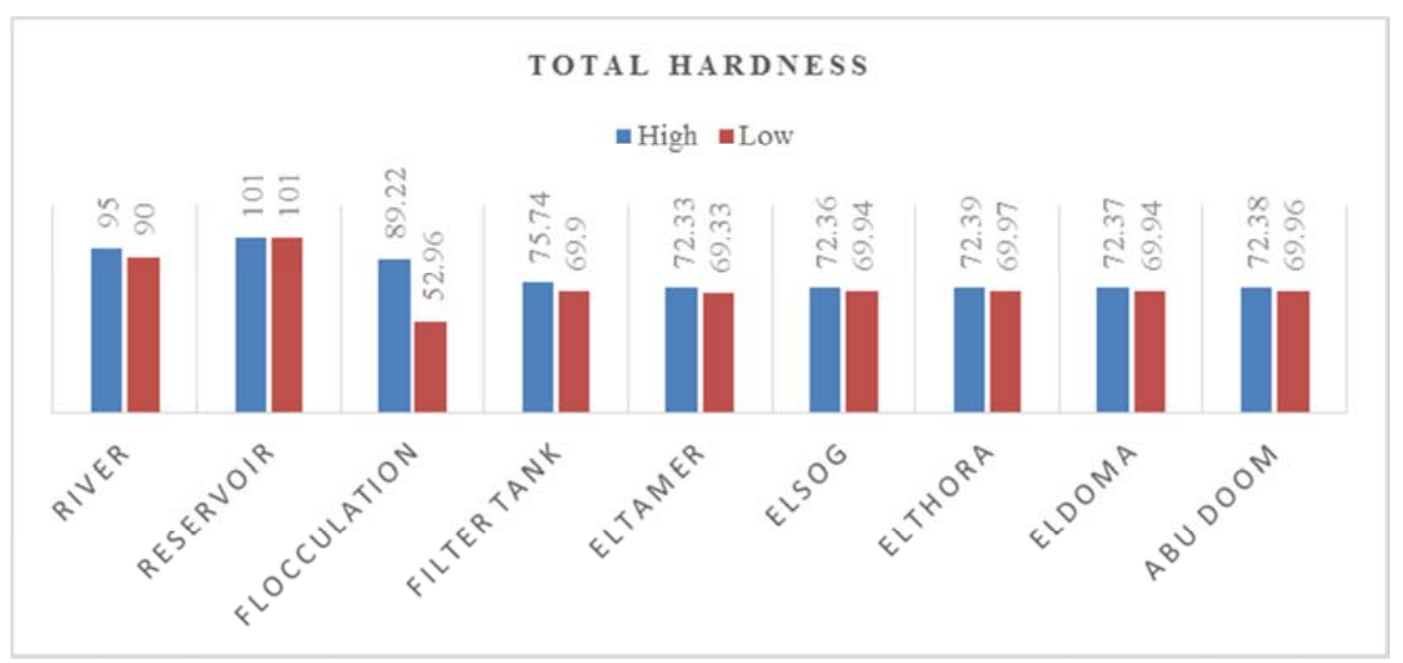

Figure 5. Total hardness values level among various types of drinking water sources in Merowe city.

\subsection{Total Dissolved Solids (TDS)}

High concentrations of total dissolved solids may cause adverse taste effects. From table 1, figure 6 TDS values varied rom 101.56 to $167.13 \mathrm{mg} / \mathrm{L}$. The all investigated samples showed within the normal limit prescribed by WHO.

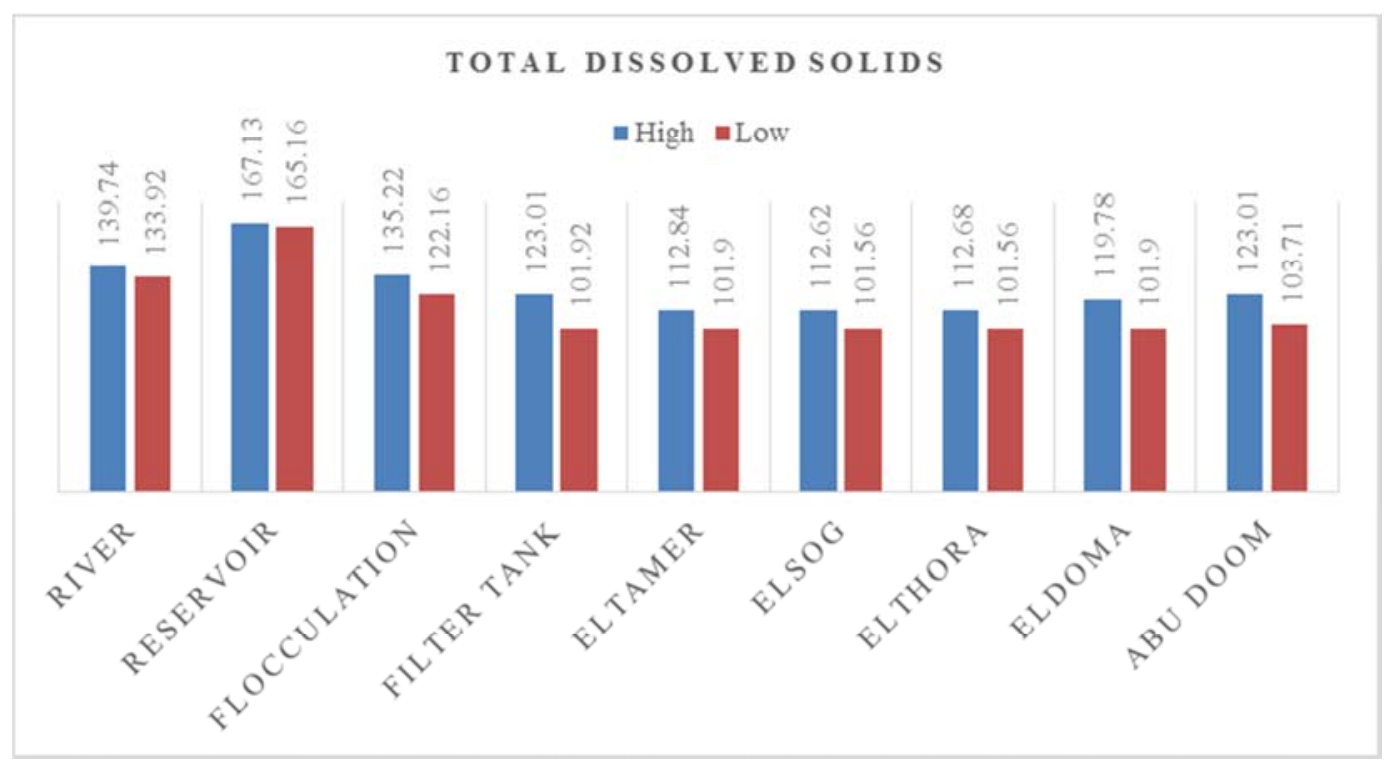

Figure 6. Total dissolved solids (mg/l) level among various types of drinking water sources in Merowe city.

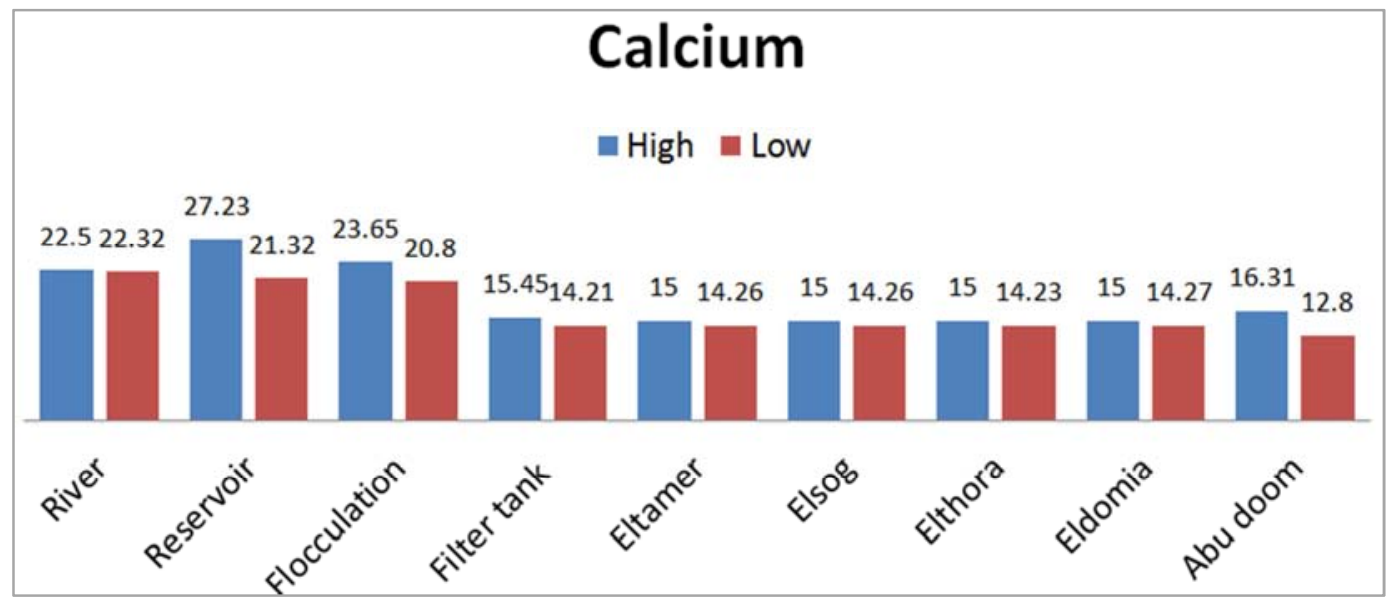

Figure 7. Concentration of $\mathrm{Ca}+2(\mathrm{mg} / \mathrm{l})$ level among various types of drinking water sources in Argo city. 


\subsection{Calcium}

Calcium is an important nutrient for aquatic, organism and it is commonly present in all water bodies. From, figure 7 the calcium concentration varied from 12.8 to $27.23 \mathrm{mg}$ which were found less than permissible range. The decrease in amount of calcium may be due to its absorption by living organisms [9].

\subsection{Sulphate}

The sources of sulphate in underground watersmay be rocks, geological formation, From, figure 8 the sulphate values of water samples varied between 3.23 to $22.29 \mathrm{mg}$, this values are less than the range of (SSMO). Sulphates are formed due to the decomposition of various sulphur containing substances present in water bodies. The sulphate ions $\left(\mathrm{SO}_{4}^{-2}\right)$ occur naturally in most water supplies and hence are also present in well waters. The values obtained for each of the three locations in this study are low compared with the WHO permissible limits and therefore are incapable of causing bad smells [10].

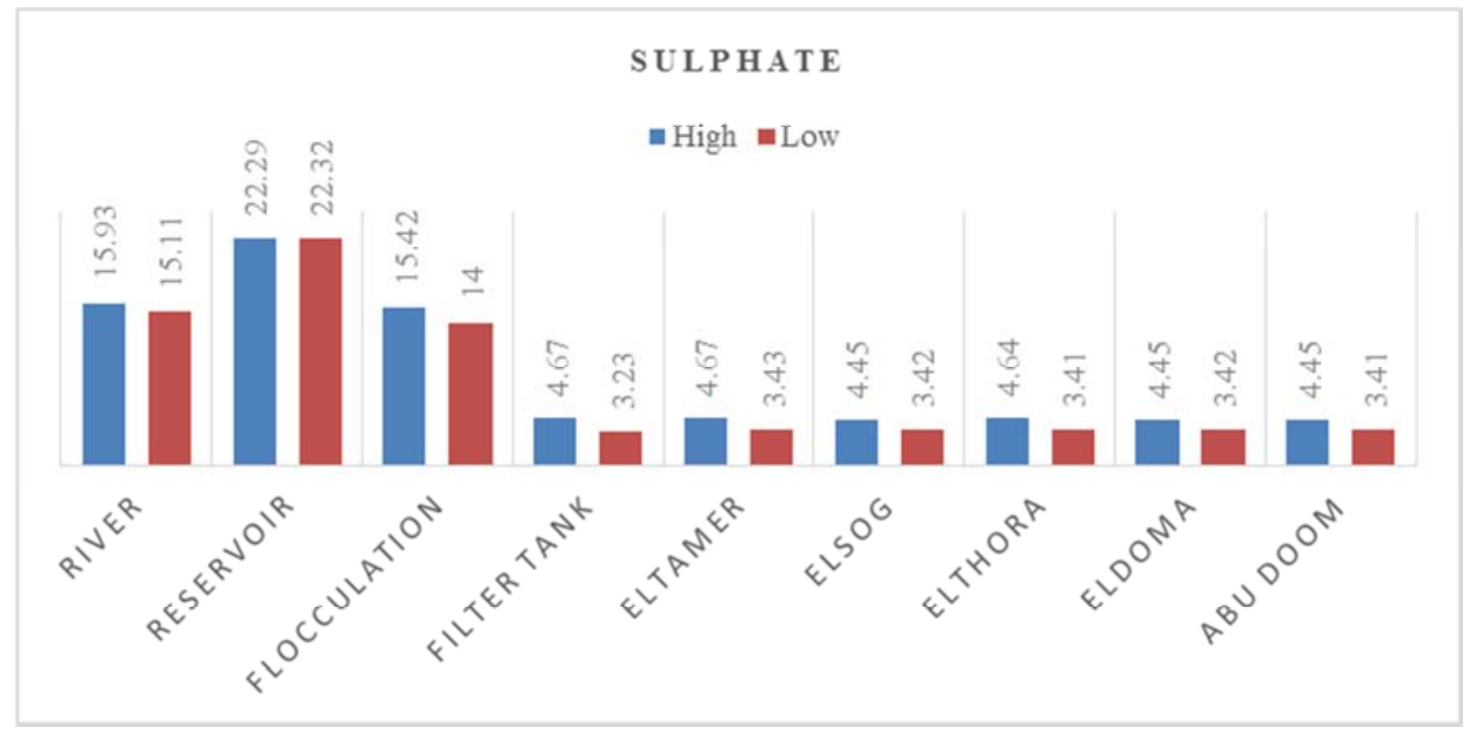

Figure 8. Concentrationof $\mathrm{SO}_{4}^{-2}(\mathrm{mg} / \mathrm{ll})$ level among various types of drinking water sources in Merowe city.

\subsection{Iron}

Iron is the most abundant element by weight in the crust. From figure 10, the iron concentration of all samples varied between 0.01 to 0.41 for samples. Which are less than the maximum value recommended by S.S.M.O.

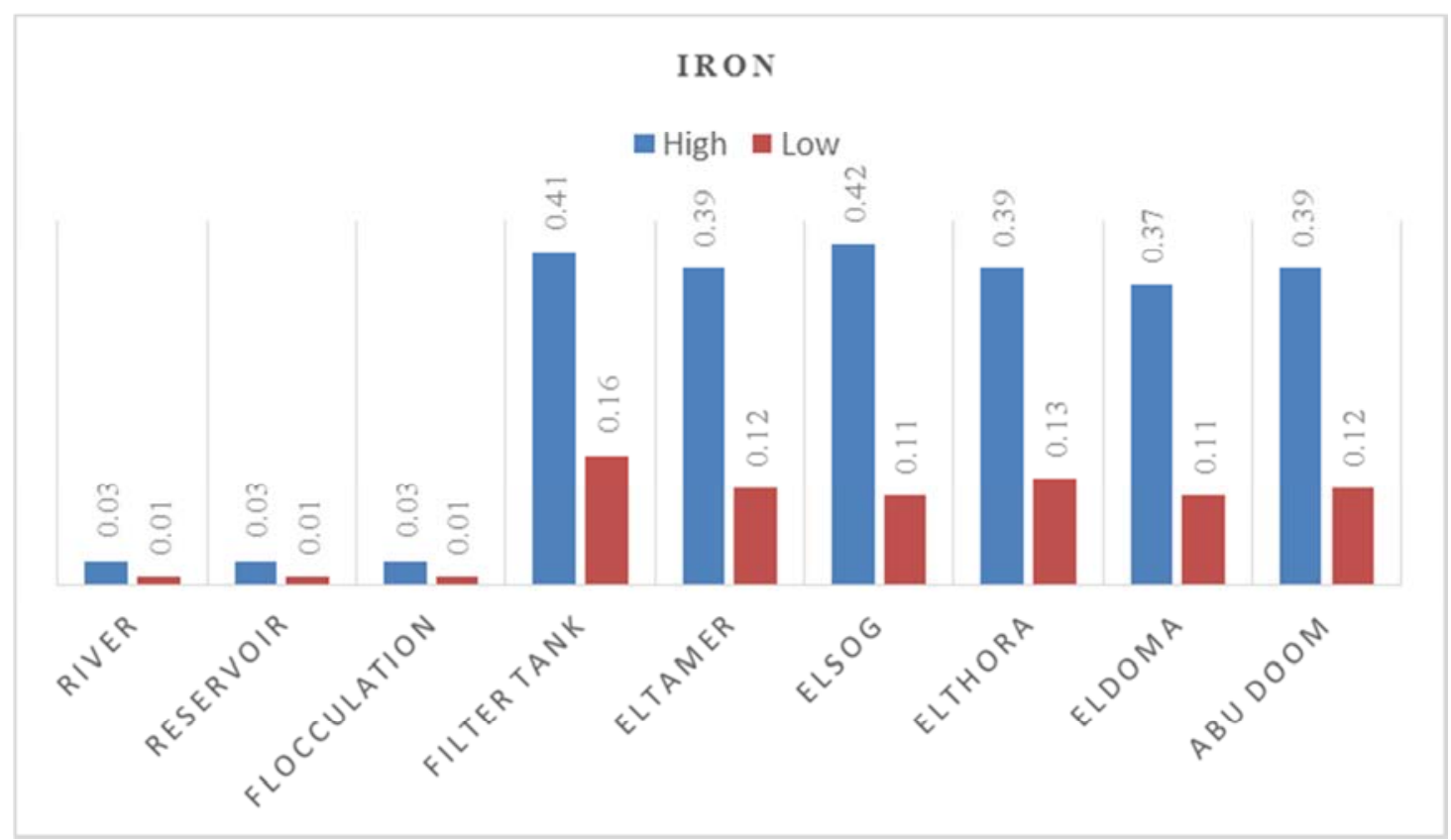

Figure 9. Concentration of Iron (mg/l) level among various types of drinking water sources in Merowe city. 


\subsection{Nitrate}

Nitrate is present in raw water and mainly it is a form of $\mathrm{N}_{2}$ compound (of its oxidizing state). Nitrate is produced from chemical and fertilizer factories, matters of animals decline vegetables, domestic and industrial discharge, From, figure 11, the nitrate was the less than the maximum range of (SSMO). Nitrates indicates the presence of fully oxidized organic matter. The mean values obtained for the fiveareas study were higher than that of WHO limits for drinking water. The implication of this is that thewell water analyzed contain high level of oxidized organic matter, which appears in the form of soluble anions such as nitrates. Excess levels of nitrates can cause Methemoglobinemia as blue baby disease. Although nitrates levels that affect infants do not pose a direct threat to older children and adults, they do indicate the possible presences of other more serious residential or agricultural contaminants such as bacteria or pesticides.

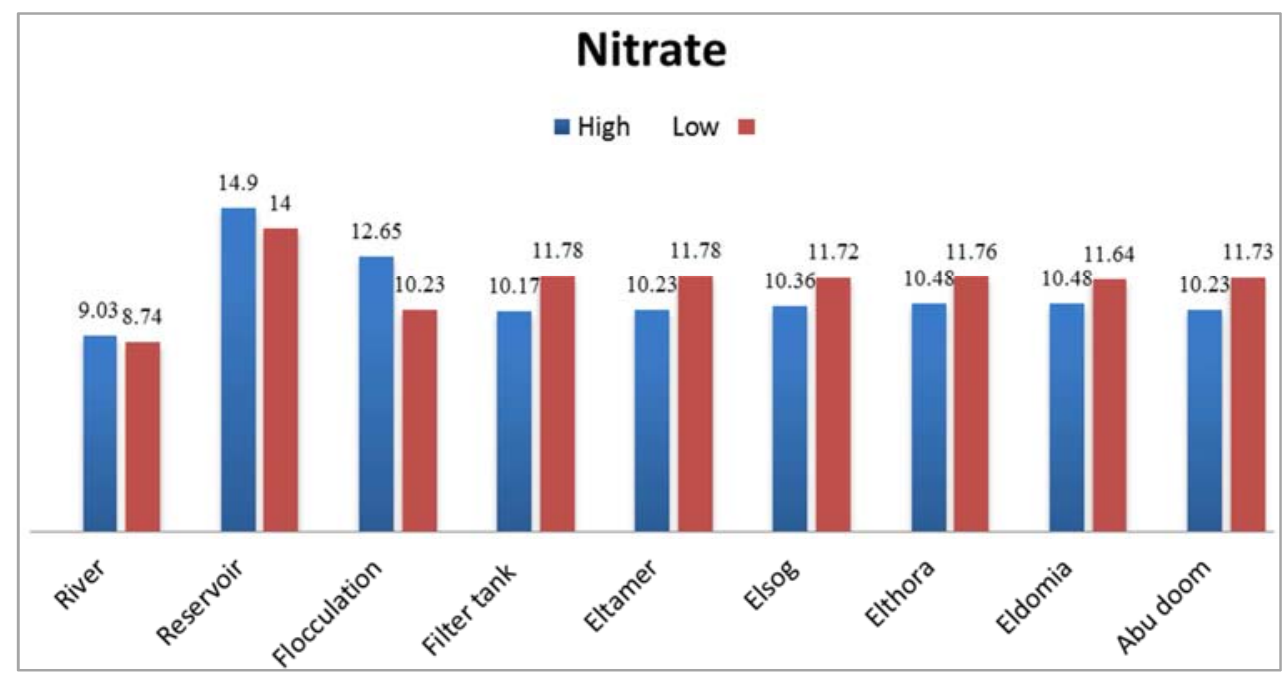

Figure 10. Concentration of Nitrate $(\mathrm{mg} / \mathrm{l})$ level among various types of drinking water sources in Merowe city.

\section{Conclusion}

The purpose of this study was assessment of drinking water quality in Merowe city north Sudan distributed the pipe line of water net work five sites of Merowe city water net work were selected comprising raw water, inside the plant, Eltamer, Elsog, Elthora, Eldom and Abu dom. Sample were collected from different area in any sample these location were selected with the aim of investigating possible pollution and diseases that might arise from human activities such as Eldoma and $\mathrm{Abu}$ doom near the farms andAbudoom. Samples were collected from river and inside the Merowe water treatment station and the pipe line of water net work. The analysis was carried for all samples using UV Spectrophotometer and flame photometer and titration. The concentration of the almost elements studies in all sample in this work are rather low compared to the maximum permissible international level provided by the World Health Organization WHO and by the Sudanese and Metrology Organization (SSMO).

\section{References}

[1] Basavaraja Simpi, S. M. Hiremath, KNS Murthy, K. N. Chandrashekarappa, Anil N Patel, E. T. Puttiah; Analysis of Water Quality Using Physico-Chemical Parameters Hosahalli Tank in Shimoga District, Karnataka, India; Global Journal of Science Frontier Research, 11 (3), 2011.
[2] Chapekar, S. B, and Mhatre, G. N., A report of the project 'Impact of Human Settelement and Developmental Activities on the Ganga River System. Institute of Science, Madam Cama Road, Mumbai (1983).

[3] Sharma, R. N. Baruah, A. K. Baruah, Bora G. C. Res., 15, 19 (1996).

[4] Akoto O. and Adiyiah, J. Chemical analysis of drinking water from some communities in the Brong Ahafo region", International Journal of Environmental Science and Technology, 4 (2), pp 211-214 (2007).

[5] Boominathan, R. and Khan, S. M., Effect of distillery effluents on $\mathrm{pH}$, dissolved oxygen and phosphate content in Uyyakundan channel water", Envionmental Ecology, 12 (4), pp 850-853 (1994).

[6] Villanveva, S. F. U. Arana A. D. G. and Madariaga, J. M. Journal of Marine systems, 72, 332 (2008).

[7] Mathur, R. P. Water and waste water testing, Nem Chand and Brothers, Publishers, Roorkee, 1-54 (1982).

[8] Gupta, D. P., Sunita and Saharan, J. P., Physiochemical Analysis of Ground Water of Selected Area of Kaithal City (Haryana) India, Researcher, 1 (2), pp 1-5 (2009).

[9] Hemkes, O. J, Kemp, A, Van, B. L. W., Accumulation of heavy metals in the soil due to annual dressings of sewage sludge, New Zealand Journal of Agricultural Sciences. 28, 228-238 (1980).

[10] Jena, P. K., Mohanty, M, Processing of liquid effluents of mineral processing industries, Intl SymposiumEnviron Manag Mining Metallurgical Industries, 11-14, Bhubaneshwar, pp 193-212 (2005). 